\title{
Drug Therapy for Prevention of Recurrent Myocardial Infarction
}

\author{
Menno E van der Elst, Henk Buurma, Marcel L Bouvy, and Anthonius de Boer
}

OBJECTIVE: To provide an evidence-based overview of drug treatment for long-term secondary prevention of myocardial infarction (MI).

DATA SOURCES: We conducted searches of MEDLINE (1966-August 2002), the Cochrane Controlled Trial Register, and the reference list of each identified study.

STUDY SELECTION/DATA EXTRACTION: Trials and meta-analyses were included using the following criteria: (1) randomized trials, (2) description of identification procedure, inclusion criteria, outcome measures, and statistical methods, (3) confirmed Mls, (4) treatment continued for at least 1 month, and (5) all-cause mortality as primary outcome; other events as secondary outcomes. All authors interpreted the results from trials that met the inclusion criteria.

DATA SYNTHESIS: In randomized clinical trials, low-dose aspirin, high-intensity oral anticoagulants, $\beta$-blockers, angiotensin-converting enzyme (ACE) inhibitors, and statins decreased the risk of mortality and reinfarction after MI. Randomized clinical trials using calcium-channel blockers, antiarrhythmics, and hormone replacement therapy did not show benefits in patients with prior MI. Effects of the combined use of aspirin or oral anticoagulants with $\beta$-blockers or ACE inhibitors plus statins must be derived from subgroup analysis of trials, but seem to be beneficial.

CONCLUSIONS: The use of at least aspirin or an oral anticoagulant, a $\beta$-blocker or an ACE inhibitor, plus a statin should be incorporated in the treatment routine. Clopidogrel treatment might be an alternative to aspirin. Standard addition of a $\beta$-blocker to ACE inhibitortreated patients without reduced left-ventricular ejection fraction seems to be untimely.

KEY WORDS: myocardial infarction, secondary prevention.

Ann Pharmacother 2003;37:1465-77.

Published Online, 22 Aug 2003, www.theannals.com, DOI 10.1345/aph.1C450

THIS ARTICLE IS APPROVED FOR CONTINUING EDUCATION CREDIT

ACPE UNIVERSAL PROGRAM NUMBER: 407-000-03-030-H01

$\mathrm{M}$ yocardial infarction (MI) is one of the most prevalent causes of death worldwide..$^{\mathbf{1 - 3}}$ Therefore, strategies to reduce mortality and cardiovascular morbidity in patients with MI have been studied extensively. Investigation of the in-hospital management of acute $\mathrm{MI}^{4-7}$ has led to the American College of Cardiology/American Heart Association $^{\mathbf{8}}$ and European Society of Cardiology ${ }^{\mathbf{9}}$ guidelines for the management of acute MI. Despite the progress in acute management, survivors of MI are still at increased risk of

\section{Author information provided at the end of the text.}

Supported by an unrestricted grant from the Scientific Institute of Dutch Pharmacists (WINAp), the Hague, Netherlands, and the SIR Institute for Pharmacy Practice Research, Leiden, Netherlands. cardiovascular mortality and morbidity. In the first year after MI, the mortality rate is $10 \%$ and remains $5 \%$ for each subsequent year. These death rates are 6 times that in people of the same age without coronary artery disease. ${ }^{\mathbf{1 0 , 1 1}}$ Guidelines for secondary prevention of MI remain inconclusive concerning combination therapy.

Given the importance of long-term secondary prevention of MI, the lack of clear recommendations concerning combination therapy in guidelines, and the widespread practice of it, an overview of evidence-based medicine after MI is timely. The objective of this article is to present an overview of pharmacologic strategies for long-term secondary prevention of MI that have been shown to be effective in lowering mortality and morbidity. Full names of clinical trials are shown in Appendix I. 


\section{Data Sources}

MEDLINE searches were conducted (1966-August 2002) with search terms myocardial infarction, secondary prevention, aspirin, antiplatelet, beta-blocker, ACE inhibitor, anticoagulant, statin, calcium-channel blocker, anti-arrhythmic, hormone replacement, and estrogen; the Cochrane Controlled Trial Register was also used. We reviewed the reference list of each identified study. All studies on pharmacologic long-term secondary prevention of MI were identified. Trials and meta-analyses were included using the following criteria: (1) randomized trials, (2) description of identification procedure, inclusion criteria, outcome measures, and statistical methods, (3) all patients had to have a confirmed MI or a subgroup analysis of data on these patients was performed, (4) the treatment continued for at least 1 month, and (5) primary outcome had to be allcause mortality; reinfarction, death from cardiac causes, stroke, or combined endpoints could be secondary outcomes. Both placebo-controlled trials and comparative studies were included to assess the effects of monotherapy and combination therapy and to differentiate specific pharmacologic regimens. All authors interpreted the results from individual trials that met the inclusion criteria. Baseline characteristics and exclusion criteria of meta-analyses on secondary prevention of MI are shown in Tables 1 and 2. ${ }^{13-18}$ Table $3^{19-58}$ presents the results of the clinical trials.

\section{Aspirin and Other Antiplatelet Agents}

The beneficial effects of antiplatelet agents including aspirin after MI have been well established by the Antiplatelet
Trialists' Collaboration. ${ }^{13}$ Their overview comprised data from 12 randomized clinical trials containing 20006 patients with a history of MI (Table 1). Overall, antiplatelet agents reduced the risk of all-cause mortality and nonfatal reinfarction compared with placebo (Table 2). ${ }^{13}$ Antiplatelet treatment also reduced the risk of vascular death (OR 0.85; 95\% CI 0.75 to 0.95), nonfatal stroke (OR 0.61; 95\% CI 0.39 to 0.83 ), and all vascular events (OR 0.75; 95\% CI 0.67 to 0.83 ). Vascular deaths comprised deaths from a cardiac, cerebrovascular, venous thromboembolic, hemorrhagic, and other vascular or unknown causes. Vascular events included nonfatal MI, nonfatal stroke, and vascular deaths. Low aspirin doses $(75-150 \mathrm{mg} / \mathrm{d})$ seemed to be as effective as aspirin doses of 160-325 and 500-1500 $\mathrm{mg} / \mathrm{d}$. ${ }^{13,59-61} \mathrm{It}$ is unclear whether doses $<75 \mathrm{mg} / \mathrm{d}$ are as effective as higher doses. ${ }^{13}$ Bleeding complications were the main adverse effects of aspirin, with intracerebral hemorrhage as the most serious manifestation, followed by gastrointestinal bleeding. Gastrointestinal adverse effects seldom result in withdrawal from treatment, and fatalities are rare. Two meta-analyses on the adverse effects of aspirin indicated that gastrointestinal adverse effects of aspirin were probably dose related. ${ }^{62,63} \mathrm{~A}$ third meta-analysis did not confirm this tendency, probably due to different definitions of adverse events. ${ }^{64}$

Dipyridamole, sulfinpyrazone, or suloctidil showed no advantages to aspirin. ${ }^{13}$ The CAPRIE trial assessed the efficacy of clopidogrel compared with aspirin in 19185 patients with MI, stroke, or peripheral artery disease. ${ }^{23}$ Clopidogrel treatment for an average of 1.9 years lowered the risk of the combined endpoint of ischemic stroke, MI, or vascular death in all patients (RR $0.93 ; 95 \%$ CI 0.83 to

\begin{tabular}{|c|c|c|c|c|c|c|c|c|c|c|}
\hline Reference & Treatment & $\begin{array}{l}\text { Years of } \\
\text { Trials } \\
\text { Reviewed }\end{array}$ & $\begin{array}{c}\text { Trials } \\
(n)\end{array}$ & Pts. (n) & PC & $\begin{array}{l}\text { Time } \\
\text { Between } \\
\text { Event and } \\
\text { Inclusion }\end{array}$ & $\begin{array}{l}\text { Duration } \\
\text { of } \\
\text { Follow- } \\
\text { Up (mo) }\end{array}$ & Age (y) & Men & $\begin{array}{l}\text { Main } \\
\text { Exclusion } \\
\text { Criteria }\end{array}$ \\
\hline APT $(2002)^{13}$ & $\begin{array}{l}\text { antiplatelet } \\
\text { agents }\end{array}$ & 1974-1995 & 12 & 20006 & + & $1-5 d$ & $12-72$ & $30-80$ & $++^{\mathrm{a}}$ & $\begin{array}{l}\text { aspirin intolerance, history of Gl } \\
\text { bleeding, former cardiac surgery, } \\
\text { severe hypertension }\end{array}$ \\
\hline $\begin{array}{l}\text { Anand et al. } \\
(1999)^{14}\end{array}$ & OAC & $1960-1998$ & 31 & 10056 & + & $<90 d$ & $3-24$ & 61 & $++^{\mathrm{a}}$ & $\begin{array}{l}\text { increased risk for bleeding, need } \\
\text { for po anticoagulant treatment }\end{array}$ \\
\hline Yusuf et al. $(1985)^{15}$ & $\beta$-blockers & $1972-1985$ & 23 & 20312 & + & $\begin{array}{l}\text { days to } \\
\text { months }\end{array}$ & $1.5-48$ & $<70$ & $++^{\mathrm{a}}$ & $\begin{array}{l}\text { AV block, bradycardia, hypotension, } \\
\text { severe heart failure, COPD, age } \\
>70 \text { y }\end{array}$ \\
\hline $\begin{array}{l}\text { Freemantle et al. } \\
(1999)^{16}\end{array}$ & $\beta$-blockers & 1967-1997 & 31 & 24974 & + & $\begin{array}{l}\text { days to } \\
\text { months }\end{array}$ & $1.5-48$ & $<70$ & $++^{a}$ & $\begin{array}{l}\text { AV block, bradycardia, hypotension, } \\
\text { severe heart failure, COPD, age } \\
>70 \text { y }\end{array}$ \\
\hline Teo et al. $(1993)^{17}$ & $\begin{array}{l}\text { class I anti- } \\
\text { arrhythmics }\end{array}$ & 1961-1992 & 51 & 23229 & $+/-$ & $\begin{array}{l}\text { hours to } \\
\text { days }\end{array}$ & NA & NA & NA & $\begin{array}{l}\text { AV block, hypotension, heart failure, } \\
\text { ventricular arrhythmia }\end{array}$ \\
\hline $\begin{array}{l}\text { Amiodarone } \\
\text { Trials Meta- } \\
\text { Analysis } \\
\text { Investigators } \\
(1997)^{18}\end{array}$ & $\begin{array}{l}\text { class III } \\
\text { antiarrhyth- } \\
\text { mics (amio- } \\
\text { darone) }\end{array}$ & 1987-1997 & 8 & 5101 & + & $<60 d$ & 1.34 & 61 & $81 \%$ & $\begin{array}{l}\text { AV block, severe heart failure or } \\
\text { angina, severe hypotension, thy- } \\
\text { roid dysfunction, bradycardia }\end{array}$ \\
\hline
\end{tabular}


0.99), but failed to lower total mortality (Table 3 ). In a subgroup of MI (33\% of all patients), clopidogrel treatment tended to lower both fatal and nonfatal MI. Data on total mortality for the subgroup of MI patients were absent. Severe gastrointestinal bleeding was more frequent in the aspirin group (RR $1.49 ; 95 \%$ CI 1.17 to 1.89 ).

\section{Anticoagulants}

The effects of oral anticoagulants after MI have been studied since the 1960s. Anand and Yusuf ${ }^{14}$ classified 31 randomized trials by the intensity of oral anticoagulant treatment and the type of control treatment. They did not perform 1 meta-analysis including all trials, but performed separate meta-analyses for trials using high-intensity (international normalized ratio [INR] 2.8-4.8) and moderateintensity (INR 2-3) therapy. Baseline characteristics and exclusion criteria are shown in Table 1. High-intensity treatment in 10056 patients reduced total mortality, fatal and nonfatal reinfarctions (Table 2), stroke (OR 0.56; 95\% CI 0.43 to 0.72 ), and the combined outcome of death, reinfarction, and stroke (OR 0.59; 95\% CI 0.54 to 0.66). Moderate-intensity treatment in 1562 patients reduced fatal and nonfatal reinfarction and stroke (OR $0.47 ; 95 \%$ CI 0.27 to $0.85)$, but failed to lower total mortality.

The Sixty Plus Reinfarction study showed that discontinuation of high-intensity oral anticoagulation in patients on treatment for up to 6 years after their first MI was harmful. ${ }^{65}$ No significant differences in total mortality or MI between oral anticoagulant treatment of any intensity and aspirin were noted by Anand and Yusuf. ${ }^{14}$

The meta-analysis of Anand and Yusuf ${ }^{14}$ also revealed that bleeding complications occurred more frequently in oral anticoagulant-treated patients than in placebo-treated patients (OR 4.7; 95\% CI 4.0 to 5.6 for total bleeds; OR $6.0 ; 95 \%$ CI 4.4 to 8.2 for major bleeds). The increase in bleeding complications was related to the intensity of oral anticoagulant treatment. Compared with aspirin, the OR was 2.4 (95\% CI 1.6 to 3.6) for high- or moderate-intensity oral anticoagulant treatment.

\section{$\beta$-Blockers}

Hjalmarson et al., ${ }^{66}$ the APSI trial, ${ }^{67}$ the BHAT trial, ${ }^{68,69}$ the Norwegian Multicentre Study Group ${ }^{70}$ and the CAPRI$\mathrm{CORN}^{25}$ study all found reduced risk of all-cause mortality in patients treated with a $\beta$-blocker compared with placebo. ${ }^{25,66-70}$ One meta-analysis of $\beta$-blocker trials was published in $1985^{15}$ and another in $1999 .{ }^{16}$ Baseline characteristics and exclusion criteria are shown in Table 1. The Yusuf et al. ${ }^{15}$ meta-analysis of 23 trials involving 20312 patients showed a reduction in both total mortality and nonfatal reinfarction when $\beta$-blocker treatment was compared with placebo. In the Freemantle et al. ${ }^{16}$ meta-analysis, data on 4662 patients from 8 long-term trials were added to the data from the Yusuf et al. analysis. Again, $\beta$-blocker treatment was associated with a significant reduction in mortality (Table 2) when compared with placebo. The CAPRICORN trial differed from the other $\beta$-blocker trials, as only patients with reduced left-ventricular ejection fraction (LVEF) were included. Carvedilol treatment provided additional benefits to angiotensin-converting enzyme (ACE) inhibitor treatment in lowering mortality or nonfatal MI (Table 3). ${ }^{25}$ Although individual trials only established the benefits of acebutolol, metoprolol, propranolol, carvedilol, and timolol, both meta-analyses indicated that benefits of $\beta$-blocker treatment are a class effect. Nevertheless, $\beta$-blockers with intrinsic sympathomimetic activity appear to be

\begin{tabular}{|c|c|c|c|c|c|c|c|c|c|}
\hline \multirow[b]{2}{*}{ Reference } & \multirow[b]{2}{*}{ Treatment } & \multirow[b]{2}{*}{ Control } & \multirow{2}{*}{$\begin{array}{l}\text { Sample } \\
\text { Size (n) }\end{array}$} & \multicolumn{2}{|c|}{ Total Mortality } & \multicolumn{2}{|c|}{ Nonfatal Reinfarction } & \multicolumn{2}{|c|}{ All Reinfarctions } \\
\hline & & & & OR & $95 \% \mathrm{Cl}$ & OR & $95 \% \mathrm{Cl}$ & OR & $95 \% \mathrm{Cl}$ \\
\hline APT $(2002)^{13}$ & antiplatelet agents & placebo & 20006 & 0.88 & 0.78 to $0.98^{a}$ & 0.70 & 0.58 to $0.82^{\mathrm{a}}$ & NA & \\
\hline $\begin{array}{l}\text { Anand et al. } \\
(1999)^{14}\end{array}$ & $\begin{array}{l}\text { OAC (INR 2.8-4.8) } \\
\text { OAC (INR 2-3) } \\
\text { OAC (INR 2-4.8) } \\
\text { OAC (INR 2-4.8) + } \\
\text { aspirin }\end{array}$ & $\begin{array}{l}\text { placebo } \\
\text { placebo } \\
\text { aspirin } \\
\text { aspirin }\end{array}$ & $\begin{array}{r}10056 \\
1562 \\
3457 \\
480\end{array}$ & $\begin{array}{l}0.78 \\
0.82 \\
0.93 \\
0.74\end{array}$ & $\begin{array}{c}0.69 \text { to } 0.87^{\mathrm{a}} \\
0.63 \text { to } 1.06 \\
0.69 \text { to } 1.28 \\
\text { NS }\end{array}$ & $\begin{array}{l}\text { NA } \\
\text { NA } \\
\text { NA } \\
\text { NA }\end{array}$ & & $\begin{array}{l}0.58 \\
0.48 \\
0.88 \\
0.55\end{array}$ & $\begin{array}{c}0.52 \text { to } 0.66^{\circ} \\
0.36 \text { to } 0.63^{\circ} \\
0.63 \text { to } 1.24 \\
\text { NS }\end{array}$ \\
\hline $\begin{array}{l}\text { Yusuf et al. } \\
(1985)^{15}\end{array}$ & $\beta$-blockers & placebo & 20312 & 0.77 & 0.70 to $0.85^{a}$ & 0.74 & 0.66 to $0.83^{a}$ & NA & \\
\hline $\begin{array}{l}\text { Freemantle } \\
\text { et al. }(1999)^{16}\end{array}$ & $\beta$-blockers & placebo & 24974 & 0.77 & 0.69 to $0.85^{a}$ & NA & & NA & \\
\hline $\begin{array}{l}\text { Teo et al. } \\
(1993)^{17}\end{array}$ & class I antiarrhythmics & placebo & 23229 & 1.14 & 1.01 to 1.28 & NA & & NA & \\
\hline $\begin{array}{l}\text { Amiodarone } \\
\text { Trials Meta- } \\
\text { Analysis } \\
\text { Investigators } \\
(1997)^{18}\end{array}$ & $\begin{array}{l}\text { class III antiarrythmics } \\
\text { (amiodarone) }\end{array}$ & placebo & 5101 & 0.92 & 0.78 to 1.08 & NA & & NA & \\
\hline
\end{tabular}


Table 3. Results from Randomized Clinical Trials on Secondary Prevention of MI

\begin{tabular}{|c|c|c|c|c|c|c|c|c|c|}
\hline \multirow[b]{2}{*}{ Reference } & \multirow[b]{2}{*}{ Treatment } & \multirow[b]{2}{*}{ Control } & \multirow{2}{*}{$\begin{array}{l}\text { Sample } \\
\text { Size (n) }\end{array}$} & \multicolumn{2}{|c|}{ Total Mortality } & \multicolumn{2}{|c|}{ Nonfatal Reinfarction } & \multicolumn{2}{|c|}{ All Reinfarctions } \\
\hline & & & & & $95 \% \mathrm{Cl}$ & & $95 \% \mathrm{Cl}$ & & $95 \% \mathrm{Cl}$ \\
\hline $\begin{array}{l}\text { APRICOT-2 } \\
(2002)^{19}\end{array}$ & $\begin{array}{c}\text { aspirin + coumarin } \\
\text { median INR 2.6) }\end{array}$ & aspirin & 308 & $\infty$ & & NA & & RR 0.28 & 0.08 to $0.98^{a, b}$ \\
\hline $\begin{array}{l}\text { ASPECT-2 } \\
(2002)^{20}\end{array}$ & $\begin{array}{l}\text { aspirin + coumadin } \\
\text { mean INR } 2.4\end{array}$ & aspirin & 999 & RR 0.60 & 0.26 to 1.36 & NA & & RR 0.70 & 0.31 to 1.58 \\
\hline $\begin{array}{l}\text { WARIS II } \\
(2002)^{21}\end{array}$ & $\begin{array}{l}\text { aspirin + warfarin } \\
\text { mean INR } 2.2\end{array}$ & aspirin & 2414 & RR 1.03 & 0.78 to $1.36^{b}$ & NA & & RR 0.56 & 0.41 to $0.78^{\mathrm{a}}$ \\
\hline $\begin{array}{l}\text { CHAMP } \\
(2002)^{22}\end{array}$ & $\begin{array}{c}\text { aspirin + warfarin } \\
\text { median INR } 1.8\end{array}$ & aspirin & 5059 & RR 0.98 & 0.87 to 1.11 & NA & & RR 1.02 & 0.88 to $1.17^{\mathrm{b}}$ \\
\hline $\begin{array}{l}\text { CAPRIE } \\
(1996)^{23}\end{array}$ & clopidogrel & aspirin & 19185 & RR 0.98 & 0.87 to 1.10 & RR 0.84 & 0.70 to $1.00^{\mathrm{b}}$ & RR 0.82 & 0.70 to $0.97^{a, b}$ \\
\hline CURE $(2001)^{24}$ & clopidogrel + aspirin & aspirin & 12562 & RR 0.93 & 0.80 to $1.07^{\mathrm{b}}$ & NA & & RR 0.77 & 0.67 to $0.89^{\mathrm{a}}$ \\
\hline $\begin{array}{l}\text { CAPRICORN } \\
(2001)^{25}\end{array}$ & $\begin{array}{l}\beta \text {-blocker } \\
\text { carvedilol }\end{array}$ & placebo & 1959 & RR 0.77 & 0.60 to $0.98^{\mathrm{a}}$ & RR 0.59 & 0.39 to 0.90 & NA & \\
\hline $\begin{array}{l}\text { Nabel et al. } \\
(1991)^{26}\end{array}$ & $\begin{array}{l}\text { ACE inhibitors } \\
\text { captopril }\end{array}$ & placebo & 38 & OR 0.29 & 0.01 to 7.44 & NA & & NA & \\
\hline $\begin{array}{l}\text { PRACTICAL } \\
(1994)^{27}\end{array}$ & enalapril & placebo & 225 & OR 0.46 & 0.20 to 1.06 & NA & & NA & \\
\hline AIRE (1993) ${ }^{28}$ & ramipril & placebo & 1986 & RR 0.70 & 0.56 to $0.87^{a}$ & NA & & OR 0.93 & 0.66 to $1.32^{\mathrm{a}}$ \\
\hline $\operatorname{ECCE}(1997)^{29}$ & captopril & placebo & 208 & OR 0.71 & 0.14 to 3.67 & NA & & NA & \\
\hline TRACE $(1995)^{30}$ & trandolapril & placebo & 1749 & OR 0.73 & 0.60 to $0.88^{a}$ & NA & & OR 0.86 & 0.66 to 1.13 \\
\hline SAVE $(1992)^{31}$ & captopril & placebo & 2231 & OR 0.79 & 0.64 to $0.96^{a}$ & NA & & OR 0.75 & 0.60 to $0.95^{\mathrm{a}}$ \\
\hline HOPE $(2000)^{32}$ & ramipril & placebo & 9297 & OR 0.84 & 0.75 to $0.95^{\mathrm{a}}$ & NA & & OR 0.80 & 0.70 to $0.90^{\mathrm{a}}$ \\
\hline $\begin{array}{l}\text { Søgaard et al. } \\
(1993)^{33}\end{array}$ & captopril & placebo & 58 & OR 1.00 & 0.10 to 10.20 & NA & & NA & \\
\hline $\begin{array}{l}\text { CONSENSUS II } \\
(1992)^{34}\end{array}$ & enalapril & placebo & 6090 & RR 1.10 & 0.93 to 1.29 & RR 1.01 & 0.85 to 1.21 & NA & \\
\hline CATS $(1994)^{35}$ & captopril & placebo & 298 & OR 1.31 & 0.57 to 3.05 & NA & & OR 2.48 & 0.83 to $7.43^{a}$ \\
\hline Sharpe et al. (1991) 36 & 6 captopril & placebo & 100 & OR 1.43 & 0.27 to 7.61 & RR 0.24 & 0.03 to 2.18 & NA & \\
\hline EDEN $(1997)^{37}$ & enalapril & placebo & 356 & OR 1.48 & 0.06 to 36.56 & NA & & NA & \\
\hline DAVIT II $(1990)^{38}$ & $\begin{array}{l}\text { calcium-channel } \\
\text { blockers } \\
\text { verapamil }\end{array}$ & placebo & 1775 & RR 0.80 & 0.61 to 1.05 & NA & & RR 0.77 & 0.58 to $1.03^{\mathrm{a}, \mathrm{b}}$ \\
\hline DAVIT I $(1984)^{39}$ & verapamil & placebo & 1436 & OR 0.91 & 0.67 to 1.24 & NA & & NA & \\
\hline DAVIT III $(1997)^{40}$ & verapamil & placebo & 100 & OR 0.96 & 0.06 to 15.79 & NA & & OR 0.14 & 0.01 to $1.02^{\mathrm{a}, \mathrm{b}}$ \\
\hline CRIS $(1996)^{41}$ & & placebo & 1073 & RR 1.06 & 0.64 to 1.77 & NA & & RR 0.81 & 0.53 to $1.24^{\mathrm{a}}$ \\
\hline DEFIANT II (1997) ${ }^{42}$ & $\begin{array}{l}\text { calcium-channel } \\
\text { blockers } \\
\text { dihydropyridines }\end{array}$ & placebo & 542 & OR 0.14 & 0.02 to 1.15 & NA & & OR 0.78 & 0.35 to $1.76^{\mathbf{b}}$ \\
\hline $\begin{array}{l}\text { SPRINT I } \\
(1988 \text { and 1994) })^{43,44}\end{array}$ & & placebo & 2276 & OR 1.02 & 0.71 to 1.45 & NA & & NA & \\
\hline $\begin{array}{l}\text { SPRINT II } \\
(1988 \text { and 1994) })^{43,45}\end{array}$ & & placebo & 1358 & RR 1.33 & 0.98 to 1.80 & NA & & NA & \\
\hline $\begin{array}{l}\text { Ishikawa et al. } \\
(1997)^{46}\end{array}$ & & placebo & 936 & OR 1.36 & 0.88 to 2.10 & OR 1.75 & 0.25 to 12.48 & OR 2.02 & 0.73 to 5.62 \\
\hline MDPIT $(1988)^{47}$ & $\begin{array}{l}\text { calcium-channel } \\
\text { blockers } \\
\text { diltiazem }\end{array}$ & placebo & 2466 & RR 1.02 & 0.82 to 1.27 & RR 0.84 & 0.64 to 1.12 & NA & \\
\hline $\begin{array}{l}\text { INTERCEPT } \\
(2000)^{48}\end{array}$ & diltiazem & placebo & 874 & OR 1.03 & 0.36 to 2.97 & RR 0.79 & 0.41 to 1.50 & NA & \\
\hline $\begin{array}{l}\text { Ishikawa et al. } \\
(1997)^{46}\end{array}$ & diltiazem & placebo & 774 & OR 1.14 & 0.65 to 2.01 & OR 1.67 & 0.15 to 18.48 & OR 3.42 & 1.18 to 9.88 \\
\hline $4 S(1994)^{49}$ & $\begin{array}{l}\text { statins } \\
\text { simvastatin }\end{array}$ & placebo & 4444 & RR 0.70 & 0.58 to $0.85^{\mathrm{a}}$ & RR 0.63 & 0.54 to $0.73^{\mathrm{a}}$ & NA & \\
\hline LIPID $(1998)^{50}$ & pravastatin & placebo & 9014 & RR 0.78 & 0.69 to $0.87^{a}$ & NA & & RR 0.71 & 0.62 to $0.82^{a}$ \\
\hline HPS $(2002)^{51}$ & simvastatin & placebo & 20536 & RR 0.80 & 0.81 to $0.94^{\mathrm{a}}$ & RR 0.62 & 0.54 to 0.70 & NA & \\
\hline CARE $(1996)^{52}$ & pravastatin & placebo & 4159 & NA & & RR 0.77 & 0.61 to 0.96 & RR 0.63 & 0.38 to 1.05 \\
\hline MIRACL $(2001)^{53}$ & atorvastatin & placebo & 3086 & RR 0.94 & 0.67 to 1.31 & RR 0.90 & 0.69 to 1.16 & NA & \\
\hline HERS $(1998)^{54}$ & $\begin{array}{l}\text { hormone replacement } \\
\text { therapy }\end{array}$ & placebo & 2763 & RR 1.08 & 0.84 to 1.38 & RR 0.91 & 0.71 to 1.17 & NA & \\
\hline HERS II (2002) ${ }^{55,56}$ & & placebo & 2321 & RR 1.14 & 0.89 to 1.46 & RR 0.98 & 0.69 to 1.40 & NA & \\
\hline $\begin{array}{l}\text { HERS + HERS II } \\
(2002)^{55,56}\end{array}$ & & placebo & 2321 & RR 1.10 & 0.92 to 1.31 & RR 0.94 & 0.77 to 1.15 & NA & \\
\hline ERA $(2000)^{57}$ & & placebo & 309 & RR 0.94 & 0.36 to $2.47^{b}$ & RR 0.88 & 0.36 to $2.17^{\mathrm{b}}$ & NA & \\
\hline WAVE (2002) ${ }^{58}$ & & placebo & 423 & RR 1.8 & 0.75 to 4.3 & RR 1.01 & 0.26 to $4.00^{b}$ & NA & \\
\hline
\end{tabular}

$\mathrm{ACE}=$ angiotensin-converting enzyme; INR = international normalized ratio; $\mathrm{MI}$ = myocardial infarction; $\mathrm{NA}$ = data not available.

aStatistically significant.

${ }^{\text {b } R R ~ o r ~ O R ~ a n d ~} 95 \% \mathrm{Cl}$ calculated based upon trial data. 
associated with reduced benefits. ${ }^{16}$ It is unclear whether cardioselectivity is a predictor of benefit, as both metaanalyses showed contradictory associations between cardioselectivity and outcome measures. Doses of $\beta$-blockers studied varied between trials. The most frequent adverse effects in the treatment groups were bradycardia and hypotension. Dizziness, depression, cold extremities, and fatigue were less common. ${ }^{10,16}$ Adverse effects were significantly more common in treatment groups than in control groups. ${ }^{68,71}$

\section{ACE Inhibitors}

The effects of ACE inhibitors after MI have been investigated in a number of randomized clinical trials, but no complete meta-analysis is available. Eleven trials including 13339 patients met the criteria. ${ }^{26-31,33-37}$ The design, baseline characteristics of randomized patients, and the use of non-study drugs are shown in Table 4. 26-39,41-48,72 The results of these trials are summarized in Table 3. In the PRACTICAL ${ }^{27}$ AIRE ${ }^{28}$ HOPE,${ }^{32}$ TRACE, ${ }^{30}$ and SAVE ${ }^{31}$ studies, the use of enalapril, ramipril, trandolapril, or captopril caused a significant reduction in total mortality. Risk of cardiac death was significantly reduced in the PRACTICAL, HOPE, SAVE, and TRACE studies. The HOPE and SAVE studies also showed a significant reduction in reinfarctions in the ACE inhibitor group. The HOPE study revealed consistent benefits of ramipril on recurrent $\mathrm{MI}$ in both patients using non-study aspirin, $\beta$-blockers, or statins and patients not using other drugs. ${ }^{73}$ In other, mostly small studies, the use of ACE inhibitors did not cause a statistically significant effect on total mortality or cardiac death. ${ }^{26,29,33-37}$ Hypotension was reported as the most frequent adverse effect. Other adverse drug reactions, such as cough, rash, dizziness, and loss of taste, were reported less frequently.

\section{Statins}

The benefits of hydroxymethylglutaryl coenzyme A inhibitors (statins) in subjects with elevated cholesterol levels have been clearly established in the $4 \mathrm{~S}$ study. ${ }^{49}$ Baseline characteristics of randomized patients and exclusion criteria of long-term trials evaluating statins are shown in Table $5 .{ }^{49-53} \mathrm{In}$ 4444 patients with angina pectoris or previous MI, simvastatin treatment reduced the risk of all-cause mortality and reinfarction (Table 3). The results from the $4 \mathrm{~S}$ study have been confirmed by the LIPID study. ${ }^{50}$ The recently published Heart Protection Study included 20536 patients with coronary disease and a broad range of cholesterol levels (total cholesterol $>135 \mathrm{mg} / \mathrm{dL}$ ) who were randomly allocated to receive simvastatin $40 \mathrm{mg} / \mathrm{d}$ or placebo. ${ }^{51}$ Baseline characteristics of randomized patients and exclusion criteria are shown in Table 5. Simvastatin treatment reduced all-cause mortality, nonfatal MI, stroke, and the need for revascularization (Table 3). There was no excess of death from noncardiovascular causes or cancer in the treatment group. Event rates were similarly and significantly reduced among both patients with and without prior
MI, patients with and without elevated cholesterol levels, men and women, and patients of all ages. The benefits of simvastatin were in addition to those of aspirin, $\beta$-blockers, and ACE inhibitors.

The CARE trial enrolled 4159 patients with a normal cholesterol level and prior MI. ${ }^{52}$ Baseline characteristics and exclusion criteria are shown in Table 5. Pravastatin treatment for a mean period of 5 years reduced the combined endpoint of death from coronary heart disease and nonfatal MI (RR 0.76; 95\% CI 0.64 to 0.91). The death rate from coronary heart disease was not reduced significantly (RR $0.80 ; 95 \%$ CI 0.61 to 1.05 ). Data on total mortality were absent. The MIRACL trial evaluated the shortterm (16 wk) effects of atorvastatin in 3086 patients who had recently experienced unstable angina or MI. ${ }^{53}$ Baseline characteristics and exclusion criteria are shown in Table 5. Atorvastatin treatment reduced the combined endpoint of death, nonfatal acute MI, cardiac arrest with successful resuscitation, and a recurrent ischemic event requiring hospitalization (RR $0.84 ; 95 \%$ CI 0.70 to 1.00 ). Atorvastatin treatment did not reduce the risk of each endpoint component except for recurrent ischemic events requiring hospitalization.

\section{Calcium-Channel Blockers}

The effects of calcium-channel blockers after MI have been investigated in many randomized clinical trials, and none of them, except for the DAVIT III pilot study, ${ }^{40}$ showed any statistically significant benefit concerning total mortality, cardiac mortality, or reinfarction. No metaanalysis that met our inclusion criteria was available. Ten randomized clinical trials evaluated long-term calcium-channel blocker treatment in patients with MI..$^{38,39,41,42,44-48,72}$ The design of the randomized clinical trials and the baseline characteristics of randomized patients are shown in Table 4. Results of these trials are summarized in Table 3.

\section{Antiarrhythmics}

The preventive effects of antiarrhythmics on mortality and morbidity after MI have been investigated, as a substantial proportion of deaths after MI is due to ventricular fibrillation. Antiarrhythmics can be subdivided into 4 major classes. The effects of class II ( $\beta$-blockers) and class IV antiarrhythmics (diltiazem, verapamil) have been discussed separately. A meta-analysis of class I antiarrhythmics reviewed 51 trials that included 23229 patients with a history of confirmed or suspected MI (Table 1). ${ }^{17}$ The risk of mortality was significantly increased in patients assigned to class I agents compared with placebo (Table 3 ). No differences were found between early and late intervention trials.

Meta-analysis of the class III antiarrhythmic amiodarone comprised 8 trials including 5101 patients with a history of MI. ${ }^{18}$ Baseline characteristics and exclusion criteria of these patients are shown in Table 1. Amiodarone treatment tended to lower the risk of total mortality (Table 3). 


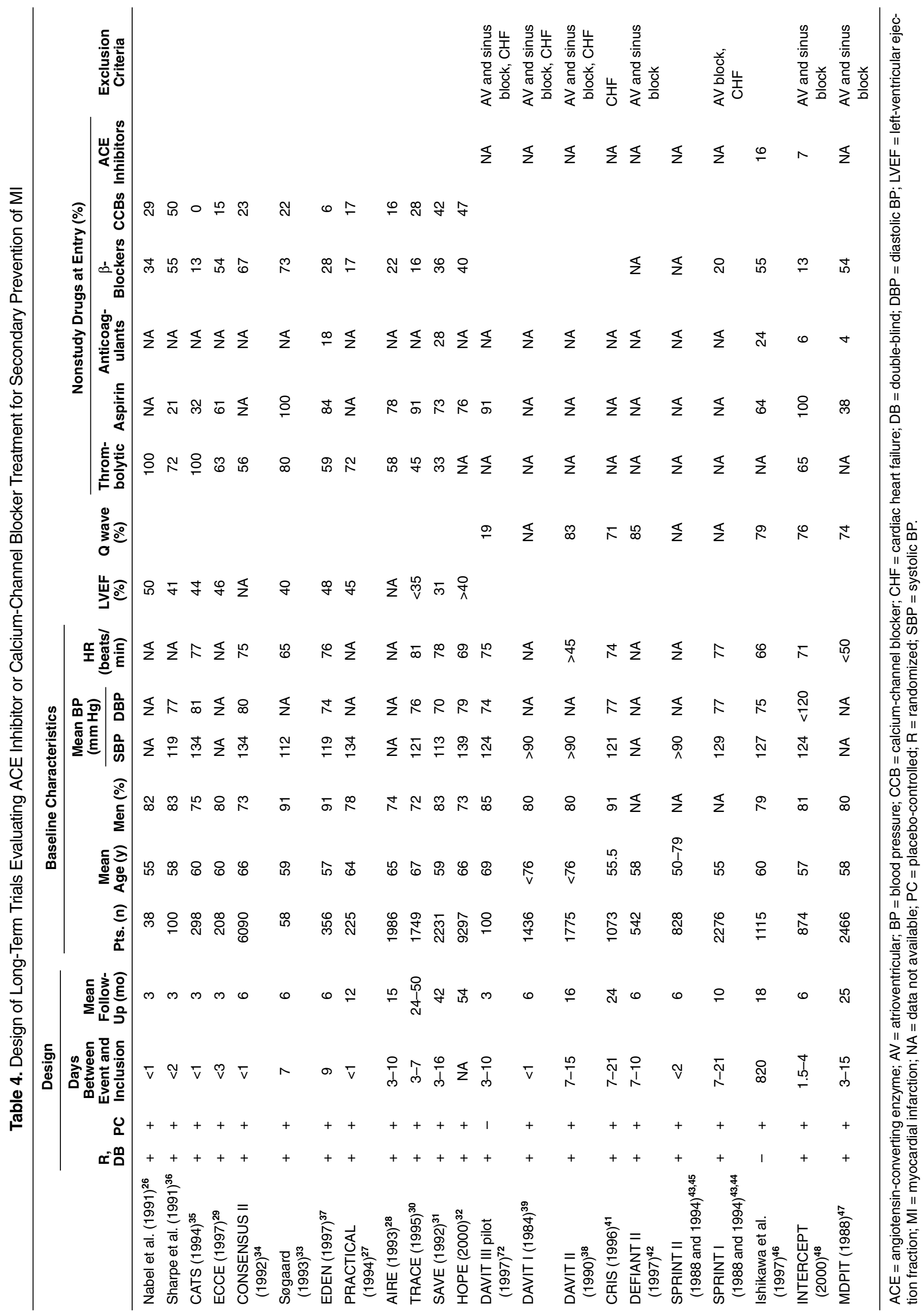




\section{Hormone Replacement Therapy}

HERS was the first randomized trial designed to investigate the effects of estrogen plus progestin therapy on cardiovascular events in postmenopausal women with established coronary disease. ${ }^{54,55}$ Half the women included had a history of MI. The trial revealed no significant differences in total mortality, MI, or any other outcome between 1380 women treated with conjugated equine estrogens $0.625 \mathrm{mg}$ plus medroxyprogesterone acetate $2.5 \mathrm{mg}$ and 1383 women receiving placebo for an average of 4.1 years (Table 3).${ }^{54}$ Subsequent unblinded follow-up of 2321 women for 2.7 years in the HERS II trial also showed no decreases in the rates of MI or death from cardiac heart disease. ${ }^{54,55}$ The first HERS trial found an excess of cardiac heart disease events in year 1 and fewer cardiac heart disease events in years 4 and 5 . This time trend disappeared after the entire 6.8 years of follow-up of HERS plus HERS II. Venous thromboembolic events occurred more often in women on hormone replacement therapy (HR 2.08; 95\% CI 1.12 to 3.40) during the entire follow-up of 6.8 years. ${ }^{56}$

The ERA study was designed to evaluate the effects of hormone replacement therapy on the progression of coronary arteriosclerosis. ${ }^{57}$ Half the women included had a history of MI. Treatment with conjugated estrogen $0.625 \mathrm{mg}$ or conjugated estrogen $0.625 \mathrm{mg}$ plus medroxyprogesterone acetate $2.5 \mathrm{mg}$ per day did not alter the rates of cardiovascular mortality, fatal or nonfatal MI, and all-cause mortality compared with placebo (Table 3 ). In the WAVE study, designed to determine whether hormone replacement therapy influenced the progression of coronary artery disease, the hormone treatment seemed to increase the risk of death (RR $1.8 ; 95 \%$ CI 0.75 to 4.3 ) or the combined outcome of death, nonfatal MI, and stroke (RR 1.5; 95\% CI 0.80 to 2.9 ) in the treatment group. ${ }^{58}$

\section{Multiple Drug Treatment}

Most randomized clinical trials in secondary prevention of MI focused on monotherapy. The only trials that studied the effects of multiple drug treatment evaluated the combination of aspirin and oral anticoagulants.

The meta-analysis by Anand and Yusuf ${ }^{14}$ did not reveal significant differences in total mortality or MI between the combination of oral anticoagulants plus aspirin versus aspirin alone (Table 3). Since publication of that meta-analysis, the WARIS II $^{21}$ and APRICOT-2 ${ }^{19}$ studies showed lower risk of reinfarction when aspirin plus oral anticoagulant treatment (INR 2.2 and 2.6, respectively) was compared with aspirin alone. The ASPECT-2 study demonstrated a favorable effect of the combination of aspirin plus Coumadin (INR 2.4) compared with aspirin alone on the composite endpoint of death, MI, and stroke (HR 0.50; 95\% CI 0.27 to 0.92$).{ }^{20} \mathrm{~A}$ beneficial effect on mortality has not been demonstrated in these trials. ${ }^{19-21}$ The CHAMP study failed to reveal any clinical benefit of low-intensity warfarin therapy (INR 1.8) combined with low-dose aspirin beyond that of aspirin alone (Table 3). ${ }^{22}$ The metaanalysis revealed that bleeding complications occurred more frequently in patients who received combination therapy. ${ }^{14}$ These findings were confirmed by the ASPECT-2 study, ${ }^{20}$ the WARIS II study, ${ }^{21}$ and the APRICOT-2 study. ${ }^{19}$ However, results from WARIS II indicated a small net benefit on the combined outcome.

To establish the effects of drug combinations other than aspirin and oral anticoagulants, subgroup analyses of trials that investigated a single agent are frequently used. Results from the CCP indicate that $\beta$-blocker treatment is beneficial for all patients, regardless of concomitant drug treatment. ${ }^{74}$ Subgroup analysis of the first WARIS ${ }^{75}$ and the first ASPECT $^{76}$ study revealed that oral anticoagulants lowered

\begin{tabular}{|lcccccccccc|}
\hline \multicolumn{7}{|c|}{ Table 5. Characteristics and Main Exclusion Criteria of Long-Term Double-Blind, Placebo-Controlled Trials } \\
Evaluating Statin Treatment for Secondary Prevention of Ml
\end{tabular}


mortality both in the presence and absence of $\beta$-blocker treatment. In the CAPRICORN study, patients with LVEF $<40 \%$ benefited from $\beta$-blocker treatment even when treated concomitantly with an ACE inhibitor. ${ }^{25}$ Meta-analysis of $\beta$-blocker trials revealed no time trend in risk reduction of cardiovascular events and death among trials performed over several decades, although concomitant drug treatment changed markedly over time. ${ }^{16}$

Studies of ACE inhibitors were performed when the use of aspirin and $\beta$-blockers became established and was reported in most cases. In the HOPE trial, beneficial effects of ACE inhibitors were observed whether or not patients were taking aspirin, $\beta$-blockers, or lipid-lowering agents. ${ }^{32}$ In a retrospective analysis of the SOLVD, HOPE, AIRE, TRACE, and SAVE trials, the benefits of ACE inhibitor treatment were apparent both in the presence and absence of aspirin, although there was a significantly smaller effect of ACE inhibitor treatment on reinfarction..$^{77}$ Retrospective analysis of the CONSENSUS II study revealed negative interaction between ACE inhibitors and aspirin ${ }^{78}$ although that interaction was absent in the CATS trial, ${ }^{79}$ the JAMIS trial, ${ }^{61}$ and the Co-operative Cardiovascular Project. The Heart Protection Study indicated that benefits of simvastatin treatment were largely independent of the use of as- pirin, $\beta$-blockers, and ACE inhibitors. ${ }^{51}$ The considerable use of aspirin in the CARE ${ }^{52}$ and LIPID $^{50}$ trials ( $83 \%$ of all participants) might indicate that the beneficial effects of statin treatment are independent of aspirin use.

\section{Discussion}

Low-dose aspirin (75-150 mg/d), high-intensity oral anticoagulant treatment (INR 2.8-4.8), $\beta$-blockers, ACE inhibitors, and statins are effective in lowering the risk of mortality and reinfarction after MI; therefore, these agents are recommended under the conditions shown in Figure 1. These recommendations are based upon the present evidence, regardless of cost effectiveness. The minimal duration of treatment can be derived from results of randomized clinical trials. Therefore, treatment with aspirin, $\beta$ blockers, or ACE inhibitors should continue for at least 2-4 years, ${ }^{13,16,28,30-32}$ and statin treatment should continue for at least $2-5$ years. ${ }^{51,52}$ As far as oral anticoagulant treatment is concerned, treatment should continue for at least 6 years, since results from the Sixty Plus Reinfarction study showed that discontinuation of oral anticoagulant treatment in patients receiving oral anticoagulants since their first MI 6 years ago was harmful. ${ }^{65}$ As beneficial effects re-

\section{START - All patients with myocardial infarction - START}

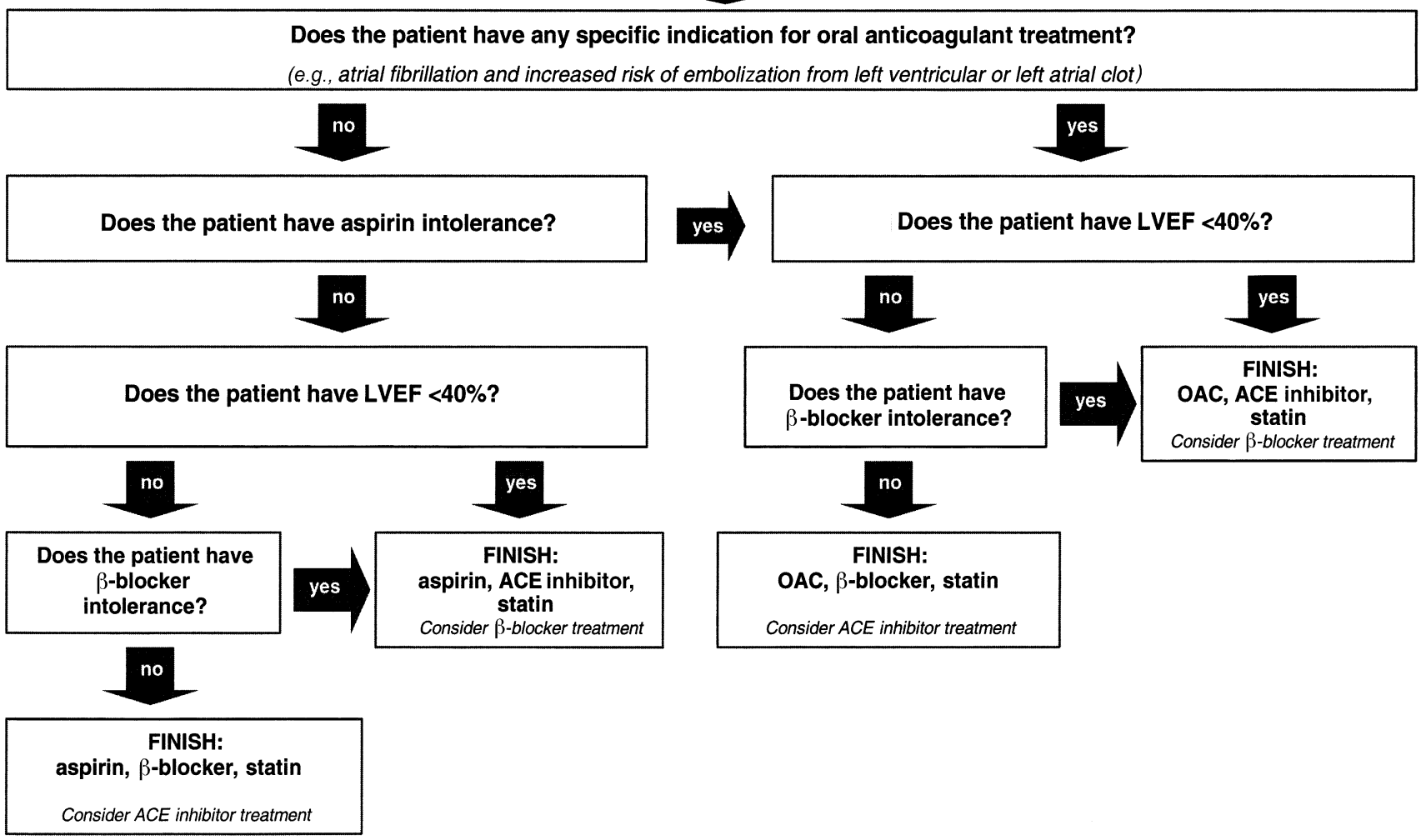

Figure 1. Flowchart for choosing drug treatment for secondary prevention of MI unless contraindications exist. ACE = angiotensin-converting enzyme; LVEF = left-ventricular ejection fraction; OAC = oral anticoagulant. 
mained apparent during the entire follow-up period and nothing pointed to the disappearance of the established effects shortly after the end of follow-up, we recommend lifelong treatment.

The expected benefits of lifelong treatment have to be evaluated in observational studies to rule out the absence of benefits in the long term. Clopidogrel treatment could be an alternative or addition to aspirin, but its mortalitylowering properties have yet to be established. The use of ACE inhibitors in patients without reduced LVEF and the use of $\beta$-blockers in patients with reduced LVEF probably are beneficial. Addition of an ACE inhibitor to $\beta$-blocker treatment or a $\beta$-blocker to ACE inhibitor treatment could be considered. Calcium-channel blockers, antiarrhythmics, and hormone replacement therapy should not be recommended for lowering cardiovascular mortality or morbidity after MI, as treatment with these agents did not show benefit for secondary prevention.

Oral anticoagulant and clopidogrel treatment are second-choice agents after low-dose aspirin $(75-150 \mathrm{mg} / \mathrm{d})$. The evidence for benefits of clopidogrel above aspirin is poor, although the size of the CAPRIE trial should have had enough power to clearly demonstrate such benefits. ${ }^{23}$ Oral anticoagulant treatment seems to provide no additional benefits in reducing MI and mortality compared with aspirin. Furthermore, oral anticoagulant treatment requires monitoring and increases the risk of bleeding complications. Therefore, oral anticoagulants are indicated for patients with other indications specific for this treatment, such as atrial fibrillation or increased risk of embolization from left ventricular or left atrial clot. Low- to medium-intensity oral anticoagulant treatment (INR 2-3) is not suitable after MI, as it did not reduce mortality. Combination therapy of aspirin and oral anticoagulants did not lower total mortality, although the CHAMP study should have had enough power to demonstrate differences in total mortality. ${ }^{14,22}$ The effects of combination therapy on reinfarctions as shown in clinical trials are conflicting. ${ }^{19-22}$ Therefore, recommendation of concomitant aspirin and oral anticoagulants is inappropriate.

The benefits of $\beta$-blockers seem to be a class effect, but most evidence is available for metoprolol, timolol, and propranolol. The dosage of metoprolol should be $100 \mathrm{mg}$ twice daily, as this dose was administered in almost all trials on secondary prevention of MI. ${ }^{16,71}$ Timolol should be dosed at $10 \mathrm{mg}$ twice daily as applied in secondary prevention trials. The lack of cardioselectivity probably will prevent broad use of propranolol. In patients eligible for ACE inhibitor treatment, captopril, enalapril, ramipril, and trandolapril should be preferred, as these agents have been shown to be beneficial and the supposed class effect has not been clearly established. The benefits of ACE inhibitors in patients with normal LVEF are less clear, as the positive results from the HOPE study ${ }^{32}$ were inconsistent with the negative results from the CONSENSUS II trial. ${ }^{34}$ Possibly, the short duration of follow-up or the high rate of concomitant use of $\beta$-blockers contributed to the absence of benefits in the CONSENSUS II trial. ${ }^{34}$ In patients with re- duced LVEF, the addition of carvedilol to ACE inhibitor treatment seems to be appropriate as demonstrated in the CAPRICORN trial. ${ }^{25}$

In randomized clinical trials, long-term statin treatment after MI was beneficial, regardless of gender, age, cholesterol level, and additional cardioprotective treatment after MI. Significant results from the Heart Protection Study were supported by trends from the CARE trial. ${ }^{51,52}$ The CARE trial probably lacked statistical significance due to the small number of patients included. ${ }^{22}$ Benefits of statin treatment in patients aged $\geq 70$ years have been established in the Heart Protection Study, but statin treatment might be beneficial in patients $\geq 74$ years of age as well, according to the results from the observational Cardiovascular Health Study. ${ }^{51,81}$ Results from short-term trials shortly after MI are promising yet inconclusive. Trends revealed by the short-term MIRACL study ${ }^{53}$ were supported by observational studies. The RISK-HIA study, ${ }^{82}$ a study by Bybee et al., ${ }^{83}$ and a study using data from the GUSTO IIb and PURSUIT trials ${ }^{84}$ revealed that prescription of lipid-lowering drugs for patients with MI was associated with reduced short-term mortality of the same magnitude as $\beta$-blocker treatment.

Positive results from observational studies using hormone replacement therapy after MI were inconsistent with results from randomized trials that failed to show benefits of hormone replacement therapy. ${ }^{54,55,57,58,85-88}$ In these studies, however, patients were not randomly assigned to receive hormone replacement therapy or placebo, so women with healthy behavior probably used postmenopausal hormones more often. A subsequent lower risk of cardiovascular disease in hormone-treated women could thus have been caused by selection bias. At present, hormone replacement therapy should not be offered for the prevention of cardiovascular disease, but could be offered to women with menopausal symptoms or osteoporosis.

Combination therapy is already widespread in daily practice, whereas conclusive evidence from randomized clinical trials that compare different strategies to reduce mortality and morbidity after MI is not yet available. Limited data, however, indicate that the beneficial effects of statins are apparent in the presence of aspirin, $\beta$-blockers, and/or ACE inhibitors, ${ }^{51}$ as well as the effects of ACE inhibitors being apparent in the presence of aspirin, $\beta$-blockers, and/or statins. ${ }^{77}$ The combination of oral anticoagulant and aspirin treatment lowered the risk for some combined endpoints but failed to lower total mortality. Given the increase of bleeding complications, combination therapy seems to provide too few benefits. Most data on combination therapy come from subgroup analyses. These results have to be interpreted with great care, as patients were randomly assigned to receive only 1 agent, whereas treatment with the other drug was not distributed by chance. Treatment with this not randomly assigned agent could be indicative for prognosis after MI. While awaiting randomized trials with combination therapy, use of results from subgroup analyses seems to be the best option to help practitioners decide on appropriate therapy, but awareness for bias is required. 


\section{Summary}

Based upon the present evidence, healthcare professionals should do their utmost to incorporate the use of at least aspirin or an oral anticoagulant, a $\beta$-blocker, or an ACE inhibitor, along with a statin in treatment routine. Clopidogrel treatment could be an alternative to aspirin as soon as benefits of clopidogrel on lowering mortality have been established in patients with MI. Addition of a $\beta$-blocker to ACE inhibitor-treated patients without reduced LVEF can be considered, although the evidence for advantage over monotherapy is limited. The same applies to the addition of an ACE inhibitor to $\beta$-blocker-treated patients with reduced LVEF.

Menno E van der Elst PharmD, PhD Candidate, Utrecht Institute for Pharmaceutical Sciences, Department of Pharmacoepidemiology and Pharmacotherapy, Utrecht University, Utrecht, Netherlands Henk Buurma PharmD, Director, SIR Institute for Pharmacy Practice Research, Leiden, Netherlands

Marcel L Bouvy PhD PharmD, Senior Researcher, SIR Institute for Pharmacy Practice Research; Utrecht Institute for Pharmaceutical Sciences, Department of Pharmacoepidemiology and Pharmacotherapy, Utrecht University

Anthonius de Boer MD PhD, Professor, Utrecht Institute for Pharmaceutical Sciences, Department of Pharmacoepidemiology and Pharmacotherapy, Utrecht University

Reprints: Menno E van der Elst PharmD, Utrecht Institute for Pharmaceutical Sciences, Department of Pharmacoepidemiology and Pharmacotherapy, Utrecht University, PO Box 80.082, 3508 TB, Utrecht, Netherlands, FAX 3130 2539166, m.e.vanderelst@ pharm. uu.nl

\section{References}

1. Demographic yearbook 1997. English/French ed. New York: United Nations Publishing Division, 1998.

2. Statline. Important primary causes of death: Statistics Netherlands, 2000.

3. American Heart Association. 2002 Heart and stroke statistical update. Dallas, TX: American Heart Association, 2001.

4. Randomised trial of intravenous streptokinase, oral aspirin, both, or neither among 17,187 cases of suspected acute myocardial infarction: ISIS2. ISIS-2 (Second International Study of Infarct Survival) Collaborative Group. Lancet 1988;2:349-60.

5. Randomised trial of intravenous atenolol among 16027 cases of suspected acute myocardial infarction: ISIS-1. First International Study of Infarct Survival Collaborative Group. Lancet 1986;2:57-66.

6. ISIS-4: a randomised factorial trial assessing early oral captopril, oral mononitrate, and intravenous magnesium sulphate in 58,050 patients with suspected acute myocardial infarction. ISIS- 4 (Fourth International Study of Infarct Survival) Collaborative Group. Lancet 1995;345:66985.

7. GISSI-3: effects of lisinopril and transdermal glyceryl trinitrate singly and together on 6-week mortality and ventricular function after acute myocardial infarction. Gruppo Italiano per lo Studio della Sopravvivenza nell'infarto Miocardico. Lancet 1994;343:1115-22.

8. Ryan TJ, Antman EM, Brooks NH, Califf RM, Hillis LD, Hiratzka LF, et al. 1999 update: ACC/AHA guidelines for the management of patients with acute myocardial infarction. A report of the American College of Cardiology/American Heart Association Task Force on Practice Guidelines (Committee on Management of Acute Myocardial Infarction). J Am Coll Cardiol 1999;34:890-911.

9. Acute myocardial infarction: pre-hospital and in-hospital management. The Task Force on the Management of Acute Myocardial Infarction of the European Society of Cardiology. Eur Heart J 1996;17:43-63.

10. Mehta RH, Eagle KA. Secondary prevention in acute myocardial infarction. BMJ 1998;316:838-42.

11. Le Feuvre CA, Connolly SJ, Cairns JA, Gent M, Roberts RS. Comparison of mortality from acute myocardial infarction between 1979 and
1992 in a geographically defined stable population. Am J Cardiol 1996; 78:1345-9.

12. Smith SC Jr, Blair SN, Bonow RO, Brass LM, Cerqueira MD, Dracup $\mathrm{K}$, et al. AHA/ACC Scientific Statement: AHA/ACC guidelines for preventing heart attack and death in patients with atherosclerotic cardiovascular disease: 2001 update: a statement for healthcare professionals from the American Heart Association and the American College of Cardiology. Circulation 2001;104:1577-9.

13. Collaborative meta-analysis of randomised trials of antiplatelet therapy for prevention of death, myocardial infarction, and stroke in high risk patients. BMJ 2002;324:71-86.

14. Anand SS, Yusuf S. Oral anticoagulant therapy in patients with coronary artery disease: a meta-analysis. JAMA 1999;282:2058-67.

15. Yusuf S, Peto R, Lewis J, Collins R, Sleight P. Beta Blockade during and after myocardial infarction: an overview of the randomized trials. Prog Cardiovasc Dis 1985;27:335-71.

16. Freemantle N, Cleland J, Young P, Mason J, Harrison J. $\beta$-Blockade after myocardial infarction: systematic review and meta regression analysis. BMJ 1999;318:1730-7.

17. Teo KK, Yusuf S, Furberg CD. Effects of prophylactic antiarrhythmic drug therapy in acute myocardial infarction. An overview of results from randomized controlled trials. JAMA 1993;270:1589-95.

18. Effect of prophylactic amiodarone on mortality after acute myocardial infarction and in congestive heart failure: meta-analysis of individual data from 6500 patients in randomised trials. Amiodarone Trials MetaAnalysis Investigators. Lancet 1997;350:1417-24.

19. Brouwer MA, van den Bergh PJ, Aengevaeren WR, Veen G, Luijten HE, Hertzberger DP, et al. Aspirin plus coumarin versus aspirin alone in the prevention of reocclusion after fibrinolysis for acute myocardial infarction: results of the Antithrombotics in the Prevention of Reocclusion In Coronary Thrombolysis (APRICOT)-2 Trial. Circulation 2002;106:65965.

20. van Es RF, Jonker JJ, Verheugt FW, Deckers JW, Grobbee DE. Aspirin and Coumadin after acute coronary syndromes (the ASPECT-2 study): a randomised controlled trial. Lancet 2002;360:109-13.

21. Hurlen M, Abdelnoor M, Smith P, Erikssen J, Arnesen H. Warfarin, aspirin, or both after myocardial infarction. N Engl J Med 2002;347:96974.

22. Fiore LD, Ezekowitz MD, Brophy MT, Lu D, Sacco J, Peduzzi P. Department of Veterans Affairs Cooperative Studies Program Clinical Trial comparing combined warfarin and aspirin with aspirin alone in survivors of acute myocardial infarction: primary results of the CHAMP study. Circulation 2002;105:557-63.

23. A randomised, blinded, trial of clopidogrel versus aspirin in patients at risk of ischaemic events (CAPRIE). Lancet 1996;348:1329-39.

24. Yusuf S, Zhao F, Mehta SR, Chrolavicius S, Tognoni G, Fox KK. Effects of clopidogrel in addition to aspirin in patients with acute coronary syndromes without ST-segment elevation. N Engl J Med 2001;345:494-502.

25. Dargie HJ. Effect of carvedilol on outcome after myocardial infarction in patients with left-ventricular dysfunction: the CAPRICORN randomised trial. Lancet 2001;357:1385-90.

26. Nabel EG, Topol EJ, Galeana A, Ellis SG, Bates ER, Werns SW, et al. A randomized placebo-controlled trial of combined early intravenous captopril and recombinant tissue-type plasminogen activator therapy in acute myocardial infarction. J Am Coll Cardiol 1991;17:467-73.

27. Foy SG, Crozier IG, Turner JG, Richards AM, Frampton CM, Nicholls MG, et al. Comparison of enalapril versus captopril on left ventricular function and survival three months after acute myocardial infarction (the PRACTICAL study). Am J Cardiol 1994;73:1180-6.

28. Effect of ramipril on mortality and morbidity of survivors of acute myocardial infarction with clinical evidence of heart failure. The Acute Infarction Ramipril Efficacy (AIRE) Study Investigators. Lancet 1993;342: 821-8.

29. Kleber FX, Sabin GV, Winter UJ, Reindl I, Beil S, Wenzel M, et al. Angiotensin-converting enzyme inhibitors in preventing remodeling and development of heart failure after acute myocardial infarction: results of the German multicenter study of the effects of captopril on cardiopulmonary exercise parameters (ECCE). Am J Cardiol 1997;80(3A):162A-7A.

30. Kober L, Torp-Pedersen C, Carlsen JE, Bagger H, Eliasen P, Lyngborg $\mathrm{K}$, et al. A clinical trial of the angiotensin-converting-enzyme inhibitor trandolapril in patients with left ventricular dysfunction after myocardial infarction. Trandolapril Cardiac Evaluation (TRACE) Study Group. N Engl J Med 1995;333:1670-6.

31. Pfeffer MA, Braunwald E, Moye LA, Basta L, Brown EJ Jr, Cuddy TE, et al. Effect of captopril on mortality and morbidity in patients with left 
ventricular dysfunction after myocardial infarction. Results of the survival and ventricular enlargement trial. The SAVE Investigators. N Engl J Med 1992;327:669-77.

32. Yusuf S, Sleight P, Pogue J, Bosch J, Davies R, Dagenais G. Effects of an angiotensin-converting-enzyme inhibitor, ramipril, on cardiovascular events in high-risk patients. The Heart Outcomes Prevention Evaluation Study Investigators. N Engl J Med 2000;342:145-53.

33. Søgaard P, Gotzsche CO, Ravkilde J, Thygesen K. Effects of captopril on ischemia and dysfunction of the left ventricle after myocardial infarction. Circulation 1993;87:1093-9.

34. Swedberg K, Held P, Kjekshus J, Rasmussen K, Ryden L, Wedel H. Effects of the early administration of enalapril on mortality in patients with acute myocardial infarction. Results of the Cooperative New Scandinavian Enalapril Survival Study II (CONSENSUS II). N Engl J Med 1992; 327:678-84.

35. Kingma JH, van Gilst WH, Peels CH, Dambrink JH, Verheugt FW, Wielenga RP. Acute intervention with captopril during thrombolysis in patients with first anterior myocardial infarction. Results from the Captopril and Thrombolysis Study (CATS). Eur Heart J 1994;15:898-907.

36. Sharpe N, Smith H, Murphy J, Greaves S, Hart H, Gamble G. Early prevention of left ventricular dysfunction after myocardial infarction with angiotensin-converting-enzyme inhibition. Lancet 1991;337:872-6.

37. Effects of enalapril on left ventricular function and exercise performance after a first acute myocardial infarction. The EDEN Study Investigators. Int J Cardiol 1997;59:257-65.

38. Effect of verapamil on mortality and major events after acute myocardial infarction (the Danish Verapamil Infarction Trial II — DAVIT II). Am J Cardiol 1990;66:779-85.

39. Verapamil in acute myocardial infarction. The Danish Study Group on Verapamil in Myocardial Infarction. Eur Heart J 1984;5:516-28.

40. Hansen JF, Hagerup L, Sigurd B, Pedersen F, Mellemgaard K, Bjergaard OP. Treatment with verapamil and trandolapril in patients with congestive heart failure and angina pectoris or myocardial infarction. The DAVIT Study Group. Danish Verapamil Infarction Trial. Am Heart J 1997;134(2 pt 2):S48-52.

41. Rengo F, Carbonin P, Pahor M, DeCaprio L, Bernabei R, Ferrara N, et al. A controlled trial of verapamil in patients after acute myocardial infarction: results of the calcium antagonist reinfarction Italian study (CRIS). Am J Cardiol 1996;77:365-9.

42. Doppler flow and echocardiography in functional cardiac insufficiency: assessment of nisoldipine therapy. Results of the DEFIANT-II Study. The DEFIANT-II Research Group. Eur Heart J 1997;18:31-40.

43. Held PH, Yusuf S. Calcium antagonists in the treatment of ischemic heart disease: myocardial infarction. Coron Artery Dis 1994;5:21-6.

44. Secondary prevention reinfarction Israeli nifedipine trial (SPRINT). A randomized intervention trial of nifedipine in patients with acute myocardial infarction. The Israeli Sprint Study Group. Eur Heart J 1988;9:354-64.

45. The secondary prevention reinfarction Israeli nifedipine trial (SPRINT) II: results (abstract). Eur Heart J 1988;9(suppl I):350A.

46. Ishikawa K, Nakai S, Takenaka T, Kanamasa K, Hama J, Ogawa I, et al. Short-acting nifedipine and diltiazem do not reduce the incidence of cardiac events in patients with healed myocardial infarction. Secondary Prevention Group. Circulation 1997;95:2368-73.

47. The effect of diltiazem on mortality and reinfarction after myocardial infarction. The Multicenter Diltiazem Postinfarction Trial Research Group. N Engl J Med 1988;319:385-92.

48. Boden WE, van Gilst WH, Scheldewaert RG, Starkey IR, Carlier MF, Julian DG, et al. Diltiazem in acute myocardial infarction treated with thrombolytic agents: a randomised placebo-controlled trial. Incomplete Infarction Trial of European Research Collaborators Evaluating Prognosis Post-Thrombolysis (INTERCEPT). Lancet 2000;355:1751-6.

49. Randomised trial of cholesterol lowering in 4444 patients with coronary heart disease: the Scandinavian Simvastatin Survival Study (4S). Lancet 1994;344:1383-9.

50. Prevention of cardiovascular events and death with pravastatin in patients with coronary heart disease and a broad range of initial cholesterol levels. The Long-Term Intervention with Pravastatin in Ischaemic Disease (LIPID) Study Group. N Engl J Med 1998;339:1349-57.

51. MRC/BHF Heart Protection Study of cholesterol lowering with simvastatin in 20536 high-risk individuals: a randomised placebo-controlled trial. Lancet 2002;360:7-22.

52. Sacks FM, Pfeffer MA, Moye LA, Rouleau JL, Rutherford JD, Cole TG, et al. The effect of pravastatin on coronary events after myocardial infarction in patients with average cholesterol levels. N Engl J Med 1996; 335:1001-9.
53. Schwartz GG, Olsson AG, Ezekowitz MD, Ganz P, Oliver MF, Waters $\mathrm{D}$, et al. Effects of atorvastatin on early recurrent ischemic events in acute coronary syndromes: the MIRACL study: a randomized controlled trial. JAMA 2001;285:1711-8.

54. Hulley S, Grady D, Bush T, Furberg C, Herrington D, Riggs B, et al. Randomized trial of estrogen plus progestin for secondary prevention of coronary heart disease in postmenopausal women. Heart and Estrogen/Progestin Replacement Study (HERS) Research Group. JAMA 1998;280: 605-13.

55. Grady D, Herrington D, Bittner V, Blumenthal R, Davidson M, Hlatky $\mathrm{M}$, et al. Cardiovascular disease outcomes during 6.8 years of hormone therapy: Heart and Estrogen/Progestin Replacement Study follow-up (HERS II). JAMA 2002;288:49-57.

56. Hulley S, Furberg C, Barrett-Connor E, Cauley J, Grady D, Haskell W, et al. Noncardiovascular disease outcomes during 6.8 years of hormone therapy: Heart and Estrogen/Progestin Replacement Study follow-up (HERS II). JAMA 2002;288:58-64.

57. Herrington DM, Reboussin DM, Brosnihan KB, Sharp PC, Shumaker SA, Snyder TE, et al. Effects of estrogen replacement on the progression of coronary-artery atherosclerosis. N Engl J Med 2000;343:522-9.

58. Waters DD, Alderman EL, Hsia J, Howard BV, Cobb FR, Rogers WJ, et al. Effects of hormone replacement therapy and antioxidant vitamin supplements on coronary atherosclerosis in postmenopausal women: a randomized controlled trial. JAMA 2002;288:2432-40.

59. Collaborative overview of randomised trials of antiplatelet therapy. I: Prevention of death, myocardial infarction, and stroke by prolonged antiplatelet therapy in various categories of patients. Antiplatelet Trialists' Collaboration. BMJ 1994;308:81-106.

60. Risk of myocardial infarction and death during treatment with low dose aspirin and intravenous heparin in men with unstable coronary artery disease. The RISC Group. Lancet 1990;336:827-30.

61. Yasue H, Ogawa H, Tanaka H, Miyazaki S, Hattori R, Saito M, et al. Comparison of the effects of alternate-day aspirin $81 \mathrm{mg}$ and daily aspirin $162 \mathrm{mg}$ on in-hospital cardiovascular events after myocardial infarction: an open-label, controlled, randomized clinical trial. Am Heart J 2000;139:930-8.

62. Roderick PJ, Wilkes HC, Meade TW. The gastrointestinal toxicity of aspirin: an overview of randomised controlled trials. Br J Clin Pharmacol 1993;35:219-26.

63. Tramer MR, Moore RA, Reynolds DJ, McQuay HJ. Quantitative estimation of rare adverse events which follow a biological progression: a new model applied to chronic NSAID use. Pain 2000;85:169-82.

64. Derry S, Loke YK. Risk of gastrointestinal haemorrhage with long term use of aspirin: meta-analysis. BMJ 2000;321:1183-7.

65. A double-blind trial to assess long-term oral anticoagulant therapy in elderly patients after myocardial infarction. Report of the Sixty Plus Reinfarction Study Research Group. Lancet 1980;2:989-94.

66. Hjalmarson A, Herlitz J, Holmberg S, Ryden L, Swedberg K, Vedin A, et al. The Goteborg metoprolol trial. Effects on mortality and morbidity in acute myocardial infarction. Circulation 1983;67(6 pt 2):I26-32.

67. Boissel JP, Leizorovicz A, Picolet H, Ducruet T. Efficacy of acebutolol after acute myocardial infarction (the APSI trial). The APSI Investigators. Am J Cardiol 1990;66:24C-31C

68. A randomized trial of propranolol in patients with acute myocardial infarction. I. Mortality results. JAMA 1982;247:1707-14.

69. A randomized trial of propranolol in patients with acute myocardial infarction. II. Morbidity results. JAMA 1983;250:2814-9.

70. Timolol-induced reduction in mortality and reinfarction in patients surviving acute myocardial infarction. N Engl J Med 1981;304:801-7.

71. The Lopressor Intervention Trial: multicentre study of metoprolol in survivors of acute myocardial infarction. Lopressor Intervention Trial Research Group. Eur Heart J 1987;8:1056-64.

72. Hansen JF, Hagerup L, Sigurd B, Pedersen F, Mellemgaard K, PedersenBjergaard $\mathrm{O}$, et al. Cardiac event rates after acute myocardial infarction in patients treated with verapamil and trandolapril versus trandolapril alone. Danish Verapamil Infarction Trial (DAVIT) Study Group. Am J Cardiol 1997;79:738-41.

73. De Geest H, Kesteloot H, Piessens J. Secondary prevention of ischemic heart disease: a long-term controlled lidoflazine study. Acta Cardiol Suppl 1979:7-116.

74. Dagenais GR, Yusuf S, Bourassa MG, Yi Q, Bosch J, Lonn EM, et al. Effects of ramipril on coronary events in high-risk persons: results of the Heart Outcomes Prevention Evaluation study. Circulation 2001;104:522- 
75. Goldbourt U, Behar S, Reicher-Reiss H, Zion M, Mandelzweig L, Kaplinsky E. Early administration of nifedipine in suspected acute myocardial infarction. The Secondary Prevention Reinfarction Israel Nifedipine Trial 2 study. Arch Intern Med 1993;153:345-53.

76. Gottlieb SS, McCarter RJ, Vogel RA. Effect of beta-blockade on mortality among high-risk and low-risk patients after myocardial infarction. $\mathrm{N}$ Engl J Med 1998;339:489-97.

77. van Bergen PF, Deckers JW, Jonker JJ, van Domburg RT, Azar AJ, Hofman A. Efficacy of long-term anticoagulant treatment in subgroups of patients after myocardial infarction. Br Heart J 1995;74:117-21.

78. Smith P, Arnesen H, Abdelnoor M. Effects of long-term anticoagulant therapy in subgroups after acute myocardial infarction. Arch Intern Med 1992;152:993-7.

79. Teo KK, Yusuf S, Pfeffer M, Torp-Pedersen C, Kober L, Hall A, et al. Effects of long-term treatment with angiotensin-converting-enzyme inhibitors in the presence or absence of aspirin: a systematic review. Lancet 2002;360:1037-43.

80. Nguyen KN, Aursnes I, Kjekshus J. Interaction between enalapril and aspirin on mortality after acute myocardial infarction: subgroup analysis of the Cooperative New Scandinavian Enalapril Survival Study II (CONSENSUS II). Am J Cardiol 1997;79:115-9.

81. Oosterga M, Anthonio RL, de Kam PJ, Kingma JH, Crijns HJ, van Gilst WH. Effects of aspirin on angiotensin-converting enzyme inhibition and left ventricular dilation one year after acute myocardial infarction. Am J Cardiol 1998;81:1178-81.

82. Krumholz HM, Chen YT, Wang Y, Radford MJ. Aspirin and angiotensin-converting enzyme inhibitors among elderly survivors of hospitalization for an acute myocardial infarction. Arch Intern Med 2001;161:538-44.

83. Lemaitre RN, Psaty BM, Heckbert SR, Kronmal RA, Newman AB, Burke GL. Therapy with hydroxymethylglutaryl coenzyme A reductase inhibitors (statins) and associated risk of incident cardiovascular events in older adults: evidence from the Cardiovascular Health Study. Arch Intern Med 2002;162:1395-400.

84. Stenestrand U, Wallentin L. Early statin treatment following acute myocardial infarction and 1-year survival. JAMA 2001;285:430-6.

85. Bybee KA, Wright RS, Williams BA, Murphy JG, Holmes DR Jr, Kopecky SL. Effect of concomitant or very early statin administration on in-hospital mortality and reinfarction in patients with acute myocardial infarction. Am J Cardiol 2001;87:771-4, A7.

86. Aronow HD, Topol EJ, Roe MT, Houghtaling PL, Wolski KE, Lincoff AM, et al. Effect of lipid-lowering therapy on early mortality after acute coronary syndromes: an observational study. Lancet 2001;357:1063-8.

87. Petitti DB. Hormone replacement therapy and heart disease prevention: experimentation trumps observation. JAMA 1998;280:650-2.

88. Grodstein F, Manson JE, Stampfer MJ. Postmenopausal hormone use and secondary prevention of coronary events in the nurses' health study. A prospective, observational study. Ann Intern Med 2001;135:1-8.

89. Heckbert SR, Kaplan RC, Weiss NS, Psaty BM, Lin D, Furberg CD, et al. Risk of recurrent coronary events in relation to use and recent initiation of postmenopausal hormone therapy. Arch Intern Med 2001;161: 1709-13.

90. Alexander KP, Newby LK, Hellkamp AS, Harrington RA, Peterson ED, Kopecky S, et al. Initiation of hormone replacement therapy after acute myocardial infarction is associated with more cardiac events during follow-up. J Am Coll Cardiol 2001;38:1-7.

\section{EXTRACTO}

PROPóSITo: Proveer una revisión basada en evidencia de la terapia farmacológica para la prevención secundaria a largo plazo de infarto al miocardio.

FUENTES DE INFORMACIóN: Se realizó una búsqueda en MEDLINE (1996

- agosto 2002 a través de Pubmed), Registro Cochrane de Estudios

Controlados y lista de referencias de cada estudio identificado.
SELECCIÓN DE FUENTES DE INFORMACIÓN Y MÉTODOS DE EXTRACCIÓN DE INFORMACIÓN: Se incluyeron estudios y análisis meta utilizando los siguientes criterios: (1) estudios aleatorios, (2) descripción del procedimiento de identificación, criterios de inclusión, medidas de resultados, y métodos estadísticos, (3) infartos al miocardio confirmados, (4) tratamiento continuo al menos por 1 mes, y (5) toda causa de mortalidad como resultado primario y otros eventos como resultados secundarios. Todos los autores interpretaron los resultados de los estudios que cumplieron con los criterios de inclusión.

SíNTESIS: Dosis bajas de aspirina, anticoagulación oral de intensidad alta bloqueadores beta, inhibidores de la enzima convertidora de angiotensina (ECA), y estatinas disminuyeron el riesgo de mortalidad y reinfarto luego de un infarto al miocardio en estudios clínicos aleatorios. Los estudios clínicos aleatorios con bloqueadores de los canales de calcio, antiarrítmicos, y terapia de remplazo hormonal no demostraron beneficios en pacientes con infarto al miocardio previo. Los efectos del uso combinado de aspirina o anticoagulantes orales con bloqueadores beta o inhibidores de ECA conjuntamente con estatinas tienen que ser derivados de un análisis de subgrupo de los estudios. Sin embargo, estos efectos parecen ser beneficiosos.

CONCLUSIONES: El uso de por lo menos aspirina o un anticoagulante oral, un bloqueador beta o un inhibidor de ECA acompañados de una estatina debe ser incorporado en el tratamiento de rutina. El tratamiento con clopidogrel puede ser una alternativa a la aspirina. La adición estándar de un bloqueador- $\beta$ a pacientes tratados con inhibidores de ECA sin fracción de eyección del ventrículo izquierdo reducida parece ser prematura.

Juan F Feliú

\section{RÉSUMÉ}

OBJECTIF: Revoir la thérapie fondée sur les preuves relativement à la prévention secondaire de l'infarctus du myocarde.

REVUE DE LITTÉRATURE: Une recherche informatisée sur la banque MEDLINE (1966 à août 2002) et la banque Cochrane Controlled Trial Register ainsi qu'une recherche à partir de la liste des références des études identifiées furent effectuées.

SÉLECTION DES ÉTUDES ET DE L'INFORMATION: Les études cliniques et les méta-analyses furent incluses selon les critères suivants: (1) étude randomisée, (2) description de la procédure d'identification, des critères d'inclusion, des mesures de l'effet, et des méthodes statistiques, (3) confirmation d'infarctus du myocarde, (4) le traitement devait continuer pour au moins 1 mois, et (5) l'effet primaire recherché était la mortalité toute cause confondue et les autres étaient secondaires. Les auteurs ont ensuite évalué les résultats des études qui ont satisfait les critères d'inclusion.

RÉSUMÉ: Dans les études randomisées, l'aspirine à faible dose, l'anticoagulothérapie à haute intensité, les $\beta$-bloqueurs, les inhibiteurs de l'enzyme de conversion de l'angiotensine (ECA), et les statines diminuent le risque de mortalité et de réinfarction après un infarctus du myocarde. Les études randomisées impliquant les antagonistes du calcium, les anti-arythmiques, et la thérapie hormonale de remplacement n'ont pas montré de bénéfices chez les patients souffrant d'un infarctus du myocarde. L'effet combiné de l'aspirine ou anticoagulation et $\beta$ bloqueur ou ECA associé aux statines doit être obtenu à partir de sous groupes d'études. Malgré cela, ces associations semblent être bénéfiques. CONCLUSIONS: L'utilisation d'au moins l'aspirine ou anticoagulant oral, d'un $\beta$-bloqueur ou d'un inhibiteur d'ECA associé à une statine devrait faire partie intégrale d'un plan de traitement. Le clopidogrel peut être une alternative à l'aspirine. L'addition standard d'un $\beta$-bloqueur à un régime impliquant un inhibiteur d'ECA chez un patient sans défaillance ventriculaire gauche (fraction d'éjection) ne semble pas encore justifiée.

Marc M Perreault 


\begin{tabular}{|c|c|}
\hline \multicolumn{2}{|r|}{ Appendix I. Acronyms of Clinical Trials } \\
\hline $4 S$ & Scandinavian Simvastatin Survival Study \\
\hline AIRE & Acute Infarction Ramipril Efficacy \\
\hline APRICOT-2 & Antithrombotics in the Prevention of Reocclusion in Coronary Thrombolysis \\
\hline APSI & Acebutolol et Prevention Secondaire de l'Infarctus \\
\hline APT & Anti-Platelet Trialists \\
\hline ASPECT-2 & Aspirin and Coumadin After Acute Coronary Syndromes \\
\hline BHAT & Beta-Blocker Heart Attack Trial \\
\hline CAPRICORN & Carvedilol Postinfarct Survival Controlled Evaluation \\
\hline CAPRIE & Clopidogrel Versus Aspirin in Patients at Risk of Ischemic Events \\
\hline CARE & Cholesterol and Recurrent Events \\
\hline CATS & Captopril and Thrombolysis Study \\
\hline $\mathrm{CCP}$ & Cooperative Cardiovascular Project \\
\hline CHAMP & Combination Hemotherapy and Mortality Prevention \\
\hline CONSENSUS II & Cooperative New Scandinavian Enalapril Survival Study II \\
\hline CRIS & Calcium Antagonist Reinfarction Italian Study \\
\hline CURE & Clopidogrel in Unstable Angina to Prevent Recurrent Events \\
\hline DAVIT & Danish Verapamil Infarction Trial \\
\hline DEFIANT & Doppler flow and Echocardiography in Functional Cardiac Insufficiency: Assessment of Nisoldipine Therapy \\
\hline ECCE & Effects of Captopril on Cardiopulmonary Exercise \\
\hline EDEN & Enalapril in Ventricular Dysfunction After Myocardial Infarction \\
\hline ERA & Estrogen Replacement and Atherosclerosis \\
\hline GUSTO Ilb & Global Utilization of Streptokinase and TPA for Occluded Coronary Arteries-II \\
\hline HERS & Heart and Estrogen/Progestin Replacement Study \\
\hline HOPE & Heart Outcomes Prevention Evaluation \\
\hline HPS & Heart Protection Study \\
\hline INTERCEPT & Incomplete Infarction Trial of European Research Collaborators Evaluating Prognosis Post-Thrombolysis \\
\hline JAMIS & Japanese Antiplatelets Myocardial Infarction Study \\
\hline LIPID & Long-Term Intervention with Pravastatin in Ischemic Disease \\
\hline MDPIT & Multicenter Diltiazem Post Infarction Trial \\
\hline MIRACL & Myocardial Ischemia Reduction with Aggressive Cholesterol Lowering \\
\hline PRACTICAL & $\begin{array}{l}\text { Comparison of Enalapril versus Captopril on Left Ventricular Function and Survival Three Months After Acute } \\
\text { Myocardial Infarction }\end{array}$ \\
\hline PURSUIT & Platelet Glycoprotein Ilb/IIla in Unstable Angina: Receptor Suppression Using Integrilin \\
\hline RISK-HIA & Swedish Register of Cardiac Intensive Care \\
\hline SAVE & Survival and Ventricular Enlargement \\
\hline SOLVD & Studies of Left Ventricular Dysfunction \\
\hline SPRINT & Secondary Prevention Reinfarction Israeli Nifedipine Trial \\
\hline TRACE & Trandolapril Cardiac Evaluation \\
\hline WARIS & Warfarin, Aspirin, Reinfarction Study \\
\hline WAVE & Women's Angiographic Vitamin and Estrogen Trial \\
\hline
\end{tabular}

